\title{
Kazimierz Rogoziński
}

Uniwersytet Ekonomiczny w Poznaniu Wydział Zarządzania

e-mail: k.rogozinski@ue.poznan.pl

\section{Wybrane kategorie określające kontekst interpretacyjny marketingu usług}

Kody JEL: M31, Z1, Z13, L89, L84

Słowa kluczowe: urzeczywistnianie, samourzeczywistnianie, sprawstwo, życie, egzystencja, dar, odpowiedzialność, dobrostan

Streszczenie. Celem artykułu jest przedstawienie sześciu wybranych kategorii marketingu usług i omówienie ich znaczenia dla istoty marketingu usług. Kontekst relacyjny marketingu usług jest podstawą interpretacji relacji usługowej, oceny roli stron w tym procesie i charakteru uzyskanego efektu.

\section{Wprowadzenie}

W niniejszym artykule zajęto się kontekstem interpretacyjnym marketingu usług. Pomijając kwestię określania jego aktualnej fazy rozwoju jako dyscypliny naukowej, uważam, iż na osiągnięcie dojrzałości teoretycznej (stadium paradygmatyczne) w decydującym stopniu wpłynąć powinno sięgnięcie po zestaw dodatkowych kategorii objaśniających. Słowo dodatkowe pojawia się nieprzypadkowo, naprowadza bowiem na zasadniczą tezę tego tekstu: poszerzenia wymagają trzy dotychczasowe domeny (i wymuszona przez nie terminologia), stanowiące podbudowę teoretyczną marketingu. Hasłowo rzecz ująwszy nazywałbym je następująco: 1) marketingiem transakcyjnym; 2) technologią; 3) scjentyzmem. Marketing transakcyjny oznacza zablokowanie teorii w/na dwu kategoriach: 
potrzebach i marce produktu oraz na imperatywie zaspokajania potrzeb, by swobodnie oddawać się pogoni za nowinkami naukowymi; technologia z kolei narzuca „stałą” w postaci innowacyjności, a oba nurty prowadzą do scjentyzmu, czego potwierdzeniem jest choćby neuromarketing. Poniżej przytaczam i pokrótce omawiam te pojęcia, które jako kategorie analityczne są niezbędne w rekonstruowaniu kontekstu interpretacyjnego marketingu usług. Ponadto pozwalają zrozumieć i obronić jego autonomiczność. Dzięki nim można dostrzec i opisać to, co wydarza się między usługodawcą a usługobiorcą, jeśli interesuje nas dotarcie do usługi „w czystej postaci”.

Sześć wyodrębnionych kategorii to nie tylko pojemne znaczeniowo pojęcia. Ich zestaw tworzy coś w rodzaju struktury polisemantycznej, bez której zrozumienie istoty działalności usługowej byłoby niepełne. Polisemantyczność kategorii jest jednocześnie odwzorowywaniem wielowymiarowej rzeczywistości, w jakiej zakorzeniony jest człowiek. Cechą je wyróżniającą jest to, że nie dają się systematyzować według dychotomicznego podziału: teoretyczne-praktyczne czy też realne-niemożliwe. Kategorie mogą być duchowe i rzeczywiste, ale też potencjalne zarazem. Służą bowiem nie tylko do opisu, ale podpowiadają sposoby przezwyciężania ograniczeń narzuconych obrazem zreifikowanej rzeczywistości (Bocheński, 1986, s. 61).

\section{Urzeczywistnianie}

Podejmując dokładniejszą analizę urzeczywistniania zapowiedzieć wypada konieczność użycia liczby mnogiej, ponieważ mieć będziemy do czynienia z trojakiego rodzaju urzeczywistnieniami. Systematyzując, poza oczywistym aspektem utylitarnym, pojawia się nadto urzeczywistnianie jako: a) samourzeczywistnianie; b) jako sprawstwo; c) odkrywanie istoty tego, co usługowe.

\section{U-rzeczywistnianie nie jest u-rzeczowieniem}

Wypada zacząć od rozróżnienia, które pozwoli uzmysłowić nam znaczenie powyższej opozycji. Występujący często w marketingu usług termin urzeczywistnianie ma dwojakie znaczenie. Otóż, po pierwsze, służy do opisu procesu przekształcania istniejącego, jedynie potencjalnie, usługowego produktu w realne korzyści dla nabywcy ${ }^{1}$. Po drugie, w bardziej popularnym rozumieniu u-rzeczywistnianie oznacza u-rzeczowienie, a więc związanie usługi czystej z jakimś materialnym podłożem, bądź dostarczeniem (jakiegoś) poświadczenia jej wykonania ${ }^{2}$. Ale ten przydatny zabieg, dotyczący zewnętrza marketingowego usługi, jest zbyt

\footnotetext{
${ }^{1} \mathrm{~W}$ czterofazowym cyklu obsługi (CLAN) oznacza tym samym przejście z fazy II do fazy III, bowiem realizacja jest urzeczywistnianiem ustaleń wypracowanych w fazie poprzedniej.

${ }^{2} \mathrm{~W}$ odniesieniu do usługi rzeczowej proponowany jest, dla odmiany, zabieg jej odmaterializowania. Por. model wzajemnych dopełnień w: Rogoziński (2000).
} 
słabą podstawą dla sądu określającego status ontologiczny usługi. Ściśle się wyrażając, można mówić o urzeczywistnianiu - rozumianym jako powoływanie do istnienia - jedynie w sytuacji, w której nie doszło jeszcze do „zafiksowania” tego, co możliwe, w rzeczowy konkret.

Chcąc zrozumieć, co znaczy u-rzeczywistniać, czyli sprawiać, by coś stało się rzeczywiste, trzeba najpierw wyjaśnić, czym jest rzeczywistość.

\section{Nieoczywistość tego, co rzeczywiste}

Czym jest rzeczywistość? To z pewnością jedno z rzadziej zadawanych pytań, nawet jeśli się uwzględni naukowców badających rzeczywistość zjawisk społeczno-ekonomicznych. Pozostawienie przywileju (komfortu?) formułowania tego rodzaju pytań jedynie filozofom, niepomiernie zubożyłoby warstwę teoretyczną chociażby nauk ekonomicznych.

Dlatego też podział na realne procesy advers. zjawiska empirycznie nieweryfikowalne mógłby być podstawą dla pytania ekonomistów o rzeczywistość gospodarczą (usługową) i realność odwzorowujących ją modeli. Za K. Jaspersem (1990, s. 129-145; 1999, s. 136-148) zauważyć wypada, że pomyślane jest nierzeczywiste, ponieważ myśląc, każdą rzecz mogę ujmować inaczej. Warianty przedstawień ograniczone zostają jednie moją sprawnością umysłową. Nie inaczej przedstawia się nam rzeczywistość fizykalna. Który jej wymiar (rozciągający się pomiędzy polem kwantowym a makrokosmosem) uznać należy za rzeczywisty? A może, jak był o tym przekonany M. Plank, realna jest tylko ta rzeczywistość, której istnienie potwierdzamy w samym momencie jej pomiaru? Czy nie jest tak, że dzięki kolosalnym postępom nauk (nie tylko fizycznych, ale także ekonomicznych, psychologicznych itd.) świat jawi się nam tylko jako to „zjawisko”, które udało się złapać w sieć pomiaru, bądź „,model” skonstruowany jak klatka-pułapka na wymykającą się rzeczywistość? Stąd już tylko niewielki krok, by wejść w second world - przesuwający granicę tego, co rzeczywiste.

Z tych szkicowo ujętych zagadnień wynika, że chociaż należy podejmować wysiłek teoretycznego wyjaśniania, czym jest rzeczywistość, to niekoniecznie wyłącznie nauka rozstrzygać powinna o tym, czy coś jest naprawdę rzeczywiste, ale raczej - egzystencja. Tu z pomocą przychodzi praktyka językowa; w wielu językach (francuski, angielski) realny jest synonimem prawdziwy (a real cat).

\section{Samourzeczywistanianie, doświadczenie teraz w samourzeczywistnianiu}

Jeśli autentyczną rzeczywistością jest taki byt, którego nie można pomyśleć jako możność, zatem tego, co autentycznie rzeczywiste, doświadczyć mogę w swoiście przeżywanym wymiarze czasu. Wieczność, jako synonim nieskończoności, albo jest samą możnością, albo wszystkimi możliwościami. Przeszłość to czas zakrzepłych nieodwracalnych zdarzeń, poza jakimikolwiek możliwościami. To, co nas interesuje i dotyczy, to niewielki prześwit między nimi, to sfera teraz 
(jeszcze jeden rodzaj „pomiędzy”), w której transcendujące jestestwo urzeczywistnia własną egzystencję, czyniąc siebie niezastępowalnym. Doświadczam tego, co rzeczywiste w samourzeczywistnianiu, dzięki utożsamianiu się ze zjawiającą się w danym momencie rzeczywistością, w jakiej żyję, a także dzięki wykorzystaniu rozpoznanych możliwości, które mam do dyspozycji. Odkrywam autentyczną rzeczywistość jedynie w perspektywie zwodniczego samourzeczywistniania; zwodniczego, bo chociaż jawi się jako rozciągnięty w czasie proces, to jego przebieg jest przecież uzależniony od mojego reagowania na to, co dzieje się teraz, ale też na to, co wydarzyło się dotąd. Utrzymywaną w stanie rozbudzenia czujnością dostrzegać mam ,głębię teraźniejszości dzięki jej podstawie leżącej w przeszłości i dzięki przestrzeni możliwego, w której wychodzi nam naprzeciw przyszłość. (...) Rzeczywistość jest tylko teraźniejsza i jako taka dziejowa i niepowtarzalna" (Jaspers, 1990).

Porządkując tę rzeczywistość, M. Archer (2013, s. 321) wyróżnia jej trzy podstawowe wymiary: a) naturalny, b) praktyczny i c) społeczny; z tego ostatniego agregatu pozwalam sobie wyjąć, i potraktować jako odrębny, wymiar d) symboliczny. Wówczas, dla każdego z wydzielanych wymiarów, określić można jego podmiotowy odpowiednik: a) dobrostan, b) kompetencje performatywne, c) poczucie własnej wartości, d) tożsamość Jaźni.

Z powyższych względów, realizacja będąca urzeczywistnianiem usługowego produktu, przez samospełnienie się usługodawcy, wiąże świadczenie z egzystencją, a przez nią otwiera się na inne Ty.

\section{Sprawstwo. Urzeczywistnianie jako sprawstwo}

Sięgam tutaj po pojęcie, które dzięki M. Archer weszło na trwałe do nauk społecznych i wyraża jedną z fundamentalnych aktywności człowieka. Nadany tutaj sprawstwu usługowy kontekst znaczeniowy ukształtowany został przez odwołanie się do pojęć pomocniczych, takich jak: praxis, praca, urzeczywistnianie, akt świadczenia, nie wyłączając samoobsługi.

Niezależnie od przyjętego poziomu szczegółowości analiz, w działalności usługowej urzeczywistnianie powinno przede wszystkim oznaczać zdolność wykonawcy do przekształcenia tego, czego zapowiedzią jest usługowy produkt (tego, co wyobrażone i antycypowane) w realne korzyści dla nabywcy.

\section{Usługowe urzeczywistnianie wartości}

Raz jeszcze sięgam po pomoc niezawodnego przewodnika po labiryntach świata, jakim jest W. Stróżewski (1992, s. 62-65). Przyjmijmy na początek, że urzeczywistnianie jest sprowadzaniem na poziom rzeczywistości czegoś, co jeszcze w niej nie tkwi, a więc istnieje poza tą rzeczywistością (potencjalnie). Unikając zbytniego skomplikowania poziomu analiz wypada rozróżnić dwie sytuacje, w których dostrzec można zjawisko tak rozumianego urzeczywistniania. 
W pierwszej, termin urzeczywistnianie użyty jest w znaczeniu potocznym; w drugiej, to samo słowo służy do wyrażenia czegoś o wiele bardziej skomplikowanego - bo urzeczywistniania wartości.

Uznawszy pracę usługodawcy za podstawowe medium urzeczywistniania wartości, której nośnikiem jest usługa - traktowana jako dobro dla nabywcy (sic!) możemy teraz wraz z W. Stróżewskim zastanowić się nad kwestią bardziej złożoną: w jaki mianowicie sposób dochodzi w świadczeniu do urzeczywistnienia wartości.

Zasadność podjęcia tej kwestii podyktowana jest choćby utrwalonym przekonaniem, że usługa jest Dobrem nie tylko w użytkowym, ale głównie w aksjologiczno-etycznym znaczeniu tego pojęcia. Dlatego pisanym $\mathrm{z}$ dużej litery. Przezwyciężenie pojawiających się trudności realizacyjnych W. Stróżewski widzi w możliwości stwarzania takich warunków, by w rzeczywistości pojawić się mógł jakiś realny odpowiednik wartości idealnej. Jeśli aspirujemy ku temu, by wytwarzane przez nas usługi były autentycznym Dobrem ${ }^{3}$ dla nabywcy, to urzeczywistnienie tego ideału zakończy się powodzeniem ${ }^{4}$, jeśli - w odpowiednio ukształtowanych warunkach - pojawia się owego Dobra realny odpowiednik.

Stwarzanie warunków odnosi się, a zarazem ogranicza, do pracy prowadzonej w tej rzeczywistości, jaka jest nam dana. Praca ta wymaga widzenia wartości, której odpowiednik pragniemy urzeczywistnić, polega zaś na takim przetwarzaniu istniejącego stanu rzeczy, aby owo urzeczywistnienie mogło się dokonać (Stróżewski, 1992, s. 62-65).

A więc, $\mathrm{z}$ jednej strony praca, sprawstwo, zaangażowanie - udzielające się stronom, uczestnikom relacji usługowej; z drugiej zaś przekonanie - jako pochodna orientacji aksjologicznej - że wytworzona dzięki pracy wartość jest nie tylko przedmiotem wiedzy i rachowania, ale też najważniejszą i najwyższą kategorią pozwalająca zrozumieć tworzoną i doświadczaną aktualnie rzeczywistość (przypomina się Kantowska władza sądzenia). Spekulatywny umysł może uznać odrębność obu, ale doświadczenie wejścia w relację usługową to odróżnienie znosi. Zatem, w świadczeniu usług najważniejsze jest doświadczenie współ/ udziału w urzeczywistnianiu wartości.

${ }^{3}$ Dobro piszę z dużej litery choćby dlatego, by odciąć się od anachronicznej dychotomii: dobra i usługi.

${ }^{4}$ Ideał - choć nie można mu przyznać obiektywnej realności, istnieje i dostarcza nam niezbędnego miernika rozumu. Rozum - potrzebne jest pojęcie tego, co w swoim rodzaju jest całkowicie zupełne, by według niego oceniać stopień i odmierzać braki tego, co niezupełne (Kant, 1957, s. 310-312). 


\section{Życie}

Daleki od zachowania ciągłości proces przekształcania się życia jako zoe (zoe w znaczeniu witalizmu właściwego wszystkim organizmom żywym) w życie jako bios (życie jednostkowe) wyrazić można również słowem: indywidualizacja. Z „gatunku” homo sapiens wyłania się indywiduum ludzkie; kosmos nabywa znaczenia dzięki kontradyktoryjności mikrokosmosu, zaś indywidualizacja zmierza ku indywiduacji. Życie kulminuje wytworzeniem, ukształtowaniem się Jaźni.

\section{Przezwyciężanie immanencji}

Chociaż dla wielu osobników ludzkich na owym wy-osobnieniu wypełnia się bycie człowiekiem, to jednak przed ambitniejszą (zawsze) mniejszością pozostaje jeszcze do spełnienia indywiduacja ${ }^{5}$. To powinno nam uświadomić, że szukając wyzwolenia z determinizmów zreifikowanego świata, poddanego prawom materii, łatwo wpaść możemy w pułapkę immanencji życia. Życie, istnienie, instynktowne parcie ku wszystkiemu, co czasowość istnienia przedłuża, wszystkie te usiłowania pozwalają dostrzec, innego rodzaju, bo instynktoidalną, immanencję życia. Z gorsetu bio/organicznych ograniczeń wyzwolić się mogę tylko doświadczając spotkania $\mathrm{z}$ tym, co wychodząc mi naprzeciw reprezentuje inny wymiar rzeczywistości. Spotykając inne Ty, w konfrontacji z nim, mogę zastanawiać się i pytać: a kim właściwie jestem, ja upominający się o zaspokojenie mojej potrzeby?

Raz dopuszczone do mojej świadomości tego rodzaju pytanie nie zadowoli się już byle jaką odpowiedzią. Spotkanie z innym Ty (jak w klasycznej relacji usługowej) okazać się może punktem zwrotnym w postrzeganiu siebie i otaczającego mnie świata. Nowe pytania, próby formułowania na nie odpowiedzi wytyczać będą równocześnie inną drogę powrotu do świata, który nie przestaje być wyłącznie moim światem. Samourzeczywistniające się Ja/ego, odkrywające nie tyle świadomość, co Jaźń, wchodzi odmienione w nasz świat. Za sprawą pomyślnie przeprowadzonej indywiduacji, wejście w świat jest powrotem odbytym już innym traktem. Wracam, odkrywając kim jestem ${ }^{6}$, wracam więc z misją jako niezastępowalny. Uwolniony od zachowań zaprogramowanych przez życie, odnajduję się w mojej egzystencji. „Jako egzystencja przemawia człowiek, który jest już sobą, który odnalazł siebie" (Jaspers, 1990, s. 138); który w żywiole życia odnalazł Logos życia.

Życie zawodowe wykonawcy ukształtowane zostaje przez stale pogłębiającą je refleksję nad byciem jako usługodawca.

\footnotetext{
${ }^{5} \mathrm{~W}$ znaczeniu nadanym jej przez C.G. Junga oznacza zwrot, zapoczątkowany odkryciem drogi prowadzącej do stawania się sobą.

${ }^{6}$ Odkrycie, o jakim tu mowa, zasadza się na podwójnie potwierdzonej tożsamości: zgodnej z samym sobą (idem) oraz rozpoznawanej jako taka sama (ipse) przez inne Ty.
} 


\section{Egzystencja}

Często, choć błędnie, egzystencja bywa rozumiana jako uciążliwości życia, albo sprowadzana do pogrążonej przez los wegetacji. Ale - jak z poniższych uwag wynika - egzystencja nie ma nic wspólnego ze znoszeniem uciążliwości życia. Egzystencja nie jest siłą, z jaką, przybrawszy postać roboty ${ }^{7}$, witalność istnienia opanowuje przyszłość. Egzystencja nie jest także, niechby nawet inteligentnym, ale zawsze reaktywnym, dostosowaniem się organizmu do otoczenia. Tyle negacji oczyszczających pole widzenia, a teraz definicja pozytywna: egzystencja nie jest też tyraniem, ani znoszeniem uciążliwości bytowania. Egzystencja jest głosem, „jakim przemawia człowiek, który jest sobą" (Jaspers, 1990, s. 109). W owym dochodzeniu do bycia sobą, bodaj najważniejsza staje się zdolność rozpoznania możliwości stojących do dyspozycji.

Egzystencja w znaczeniu jej tutaj nadawanym jest wydobyciem z conditio humana tego, że człowiek jest wolnym, przekraczającym siebie podmiotem (Jaspers, 1999, s. 144). To, że w prowadzonych tu rozważaniach egzystencja nie została wpisana jedynie w kontekst biologiczny tylko antropologiczny, wynika $\mathrm{z}$ wpisania rozumienia usługi $\mathrm{w}$ kontekst relacyjny, ukształtowany przez relationship marketing. Bycie człowiekiem uświadamiamy sobie w szczególny sposób w sytuacjach życiowo wyróżnionych. Jaspersowskie krańcowe doznania egzystencjalne to oczywiście śmierć, rozpacz, wina... ale także poczucie samotności, pustki życiowej czy też walka z przeciwnościami losu; to także dojmująca świadomość niesamowystarczalności bytowej. Ale też nie powinno się dezawuować znaczenia doznań numinotycznych, czy żarliwości czyjegoś zaangażowania. Poszukiwanie czyjejś pomocy czy przeżycie czegoś naprawdę wartościowego należą do kręgu tego rodzaju doświadczeń. Nie ma aż tak wielkiego znaczenia precyzyjne wskazywanie momentu, w jakim spotkane/wybrane inne Ty przekształca się w usługodawcę. Ważniejsza jest heureza tego skojarzenia wskazująca na moment narodzin relacji usługowej.

\section{Transcendowanie}

Chociaż bios/zoe wiążą człowieka z tym, co organiczne, to bycie człowiekiem zwykło się wyrażać za pomocą czasownika: sistit ex - (sisto, sisti, statum), czyli umieszczać, postawić poza. Mamy tu niejako archetypicznie zakodowane dwojakiego rodzaju wykraczanie/transcendowanie: poza to, co przyrodniczo-biologiczne, ale także poza samego siebie, poza takiego, jakim aktualnie jestem. Chociaż człowiek ,jest z przyrody”, to egzystując umieszcza siebie poza jej

\footnotetext{
${ }^{7}$ Tutaj wskazane byłoby uwzględnienie różnicy między robotą a pracą.
} 
domeną. Na tej podstawie można nawet wytyczyć coś w rodzaju skali dochodzenia do bycia pełniej/więcej człowiekiem ${ }^{8}$.

W antropologicznym więc sensie, egzystencja jest to wszystko, w czym potwierdzam się jako indywiduum ludzkie, co umożliwia mi dochodzenie do bycia sobą. Sedno problemu tkwi w tym, że chociaż każdy z nas dysponuje jakimś możliwościami, to sposób ich wykorzystania może przesądzić o formule dochodzenia do bycia człowiekiem. Jeśli - jak uzasadniał S. Kierkegaard - egzystencja wyprzedza esencję, faktyczności życia wyprzedza myślenie o Życiu, kiedy możliwości egzystencjalne ujawniają się i potwierdzają w trakcie ich realizacji - wówczas jestestwo spełnia się jako byt wolny, wykraczający poza rozpoznane ograniczenia. Jak powie M. Heidegger: Dasein nie może tego projektowania poniechać, bowiem jest - o ile projektuje, musi stale wybierać między możliwymi sposobami bycia; tylko że, jak trafnie zauważa K. Michalski, Dasein jest samo „faktycznym” projektem, zaś faktyczność uprzedza zakres dostępnych możliwości (Michalski, 1978, s. 84). Okazuje się, że rzeczywistość zaczyna się tam, gdzie kończy się sfera możliwego. Cóż to znaczy, jak mam to rozumieć? Chyba tak: aktualne rozpoznane przeze mnie możliwości wykorzystać w celu bycia sobą, bycia jako stawanie się w pełni człowiekiem. Dopiero wtedy moje życie nabiera sensu, kiedy rozgrywam je w świecie, ściśle w tym fragmencie rzeczywistości, który mogę współkształtować, którego Dobrostan mogę pomnażać (Elzenberg, 1991, s. 348).

\section{Rozpoznawanie tego, co możliwe}

Jeśli intencjonalny sposób zaistnienia/zjawiania się usługi uznalibyśmy za jej atrybut, tym bardziej wszystko, co dotyczy konstruktu, jakim jest usługowy produkt, musi zawierać się w sferze potencjalności. Zgodnie z tradycją Arystotelesowską, potencja/potencjalność/energia oznaczają możność, a więc to, co w jakiś sposób już jest, a równocześnie jeszcze nie jest; jest jakby w przygotowaniu, w dyspozycji - gotowości, a jeszcze nie w pełni rzeczywiste. Dopiero akt, działanie sprawcze prowadzi do urzeczywistnienia możności, do jej spełnienia (Wojtyła, 1969, s. 65). Ana/logicznie więc, to, co potencjalnie tworzy wyposażenie usługowego produktu, w procesie realizacji przejść powinno w fazę urzeczywistniania. Choć dla wykonawstwa usług jest to newralgiczny moment, próżno szukać by odpowiednich analiz w opracowaniach usługom poświęconym ${ }^{9}$.

Zgodnie z tym odróżnieniem, wydobywając przede wszystkim aspekt techniczno-funkcjonalny, możemy podać przykład „urzeczywistniania” zdolności

\footnotetext{
(M. Schelera).

${ }^{9}$ Niestety te, na jakie natrafiamy w opracowaniach z zakresu marketingu, więcej zaciemniają niż wyjaśniają, bo niby dlaczego element tworzący obudowę tzw. rdzenia produktu miałby być bardziej rzeczywisty niż sam rdzeń?
}

${ }^{8} \mathrm{~W}$ czym pomocna staje się staje nie hierarchia potrzeb (A. Maslowa), tylko system wartości 
produkcyjnych maszyny, możliwości wykonawczych ekspresu do kawy (w domu bądź w kawiarni) czy ultrasonografu (w przychodni). Sposób uruchamiania możliwości wykonawczych takich urządzeń uzmysławia nam, że pozostajemy w tym samym wymiarze rzeczywistości, której zakres i przewidywalność wyznaczone zostały parametrami techniczno-funkcjonalnymi urządzeń. Nazywanie wytwarzania rzeczy „urzeczywistnianiem potencjału produkcyjnego” jest określeniem nie tyle mało precyzyjnym, co mylącym. Poprawniejsze byłoby słowo: urzeczywistnianie zarezerwować dla urzeczywistniania wartości i odnosić je do takich sytuacji, w których człowiek wyzwalając swoją aktywność sensotwórczą sięga po usługi.

Uwaga końcowa. Analizowana tu kategoria powinna niezmiennie przypominać nam jeszcze o jednym. Myślimy i mówimy o urzeczywistnianiu usługi. Jednocześnie pamiętać powinniśmy o tym, że orientacja na to, co jednostkowe (indywiduum ludzkie i usługę) nie może przysłaniać, ani tym bardziej wypaczać, prawdy o conditio humana. Istnieje bowiem coś wspólnego, co nas łączy, jako ludzi. I chociaż każdy próbuje indywidualnie „wybić się na człowieka”, to jednak jednoczy nas nie tylko wspólnota losu, ale również usiłowanie przezwyciężenia tego, co wyłącznie organiczne. Urzeczywistnianie usługi jako wartości dlatego ma niewiele wspólnego z urzeczowieniem (reifikacją), ponieważ daje się prowadzić transcendowaniu.

\section{Dar}

Są przynajmniej trzy dostateczne powody, które uzasadniają pojawienie się kolejnej kategorii tak zatytułowanego fragmentu. Po pierwsze, jest nim zamysł wyprowadzenia istoty usługi ze zrozumienia (eksplikacji) sposobu istnienia ludzkiego jestestwa, a więc poszukiwanie uzasadnienia usług na poziomie zgodności z egzystencją. Racja wtóra nawiązuje do przyjętej i rozwijanej opcji, która pozwala postrzegać usługę jako to, co się wy-darza między stronami, uczestnikami relacji usługowej. Wy-darzyć, jak wskazuje na to trop etymologiczny, wiąże się z darzyć. Ten wspólny źródłosłów wskazuje więc na to, że usługa wydarzając się, zjawia się również jako dar. Natomiast trzeci powód thumaczący pojawienie się kategorii „daru” wynika wprost z etymologiczno-frazeologicznych konotacji. Nie do końca wyjaśnialne kształtowanie się uzusu językowego skłania do zastanowienia się nad utrwalaniem się niektórych pojęć/słów. Za znamienne uznać wypada to, że niepowodzeniem zakończona została - podjęta w latach siedemdziesiątych XX wieku - próba wprowadzania do polszczyzny słowa „usługowiec”. Życie negatywnie zweryfikowało ten pomysł, który pewnie narodził się w głowie biurokraty. Analogia ze sposobem określenia innych zawodów (handlowiec, budowlaniec, stoczniowiec...) się nie potwierdziła, pewnie dlatego, że „usługowiec” nie funkcjonuje w świecie rzeczy. W odróżnieniu od innych fachowców, sfera jego 
działania wyznaczona zostaje interakcjami/relacjami międzyludzkimi. Racją istnienia „usługo-dawcy” jest to, że spotyka „usługo-biorcę” (ale też vice versa). Podstawą kształtującą owo spotkanie jest relacja usługowa, dzięki której udaje się przekształcić wyjściową asymetrię informacji (usługodawca wie wszystko najlepiej, a usługobiorca to tabula rasa) w relację zrównoważoną. Tę równowagę osiąga się przechodząc od wymiany informacji i komunikacji do porozumiewania będącego dorozumiewaniem się sensu świadczenia. Co więcej, dzięki relacji usługowej, osiągnąwszy zaawansowany stan współpracy, może się okazać, że obowiązkowy warunek ekwiwalentności wymiany może zostać zawieszony (na jakiś czas) lub uchylony ${ }^{10}$. Wraz z tą zmianą, samo obdarowywanie przestaje być postrzegane w kategorii ofiary lub poświęcenia, ujawniając altruistyczny korzeń daru.

\section{Obdarowywanie}

Jak można zauważyć w liberalnej gospodarce rynkowej, gest (?) zjawisko (?) bezinteresownego obdarowywania (się) wyraźnie zanika. Komercjalizacja sektora usług publicznych jest tego trendu wyraźnym potwierdzeniem. Przyjmuje się, że każda wymiana sprowadzona być powinna do pierwowzoru, jakim jest wymiana towarowa. A ponieważ usługa - jako rezultat działalności gospodarczej - jest towarem, więc powinna być mierzona tą samą miarą jak każdy wyrób. W rezultacie, każde zaangażowanie czy poświęcenie dla kogoś innego przybiera postać działania interesownego. Usługodawca ogranicza się, by przypadkiem nie dać czegoś więcej, powściąga zaangażowanie, by w realizacji usługi przypadkiem nie znalazło się coś, co trudno będzie wycenić. Oznacza to zanik postaw, których motywem była bezinteresowna pomoc, tym bardziej cenna, im większego wymagała poświęcenia (np. czasu) czy ofiary (wyrzeczeń, rezygnacji z czegoś). $\mathrm{W}$ jej miejsce pojawia się zmediatyzowane zainteresowanie, albo interesowny przekaz wiedzy ${ }^{11}$, wymagające obsługi aplikacje, w jakie wyposażone zostały komunikatory. Relacje międzyludzkie, niegdyś postrzegane w kategoriach etycznych (powinność) zostają sprowadzone do wymiany informacji czy korzystania $\mathrm{z}$ baz danych. Pielęgniarkę, opiekunkę zastąpi robot, a konsultacje z promotorem, prawnikiem czy lekarzem - nieograniczony dostęp do specjalistycznych danych rozlewających się po forach internetowych.

${ }^{10} \mathrm{~W}$ relacyjnym marketingu usług, szacunek wartości relacji długookresowych (LTV) dopuszcza, by we wstępnej fazie współpracy wyznaczyć cenę usługi nawet poniżej progu opłacalności świadczenia.

${ }^{11}$ Dochodzi to tego, że zanika dyskusja naukowa, bo badacz obawia się, że jeśli w trakcie seminarium czy konferencji powie za dużo, to ktoś wykorzysta jego autorski pomysł i go skomercjalizuje. 


\section{E-service jako usługa?}

Informatyzacja usług, traktowana jako najważniejsze osiągnięcie trzeciej rewolucji przemysłowej, przynosi coraz bardziej niepokojące skutki. Spakowanie usług na elektronicznych nośnikach i udostępnianie powoduje, że korzystanie z e-usług pozbawia usługi sprawstwa, aktywności jedynie ludzkiej, rozumianej jako przeciwdziałanie niwelującemu prawu entropii tudzież nicestwieniu noosfery nadbudowującej się ponad światem ludzi. Skoro usługa przestaje być kojarzona ze świadczeniem, zaangażowaniem czy poświęceniem, więc kluczowe określenie usługodawca/usługobiorca staje się pustym słowem. Awatar może być hermafrodytą, usługodawcą/usługobiorcą jednocześnie, bo właściwie niczego nikomu nie daje, a jedynie przesyła bądź wykorzystuje informacje.

By spointować tę nader skrótowo potraktowaną kwestię, można sięgnąć po cytat. Otóż Bertold z Ratyzbony (XIII w.) w jednym ze swoich kazań napisał: „Kto by nam uprawiał rolę, gdybyśmy wszyscy byli panami” (Elias, 2011, s. 275). Więc po ośmiu wiekach można skończyć podobnym pytaniem: a kto będzie nam zmieniat pampersy, jeśli wszyscy zajęci będą e-serwisem?

\section{Zaburzona tożsamość: kto darczyńcą, a kto obdarowanym}

Powyższe, dalece niewyczerpujące ujęcie daru zakończyć można uwagą, która jest transpozycją - w usługowy kontekst - konkluzji zapożyczonej z innej polemiki ${ }^{12}$. Na szczęście można jeszcze spotkać ludzi przemyśliwujących całościowo obserwowane zjawiska. Dzięki nim to, co pozornie wydawało się niezrozumiałe, nabierać zaczyna głębszego sensu. To, co wcześniej - jako usługodawca - odbierałem w kategoriach trudu, ofiary czy poświęcenia, jawić się zaczyna jako darowanie będące dzieleniem się, stające się współ/udziałem. Zgodnie z powyższymi ustaleniami, darzenie nie oznacza umniejszania czy ubywania; jest raczej dzieleniem się niezbywalną obfitością Dobra, jakie w postaci usługi mogę współtworzyć. Obfitość jego zasobów jest rezultatem „wartości wspólnie dodanej” (Rogoziński, 2012). Jeśli wykonawca podejmuje współpracę z nabywcą, to wspólnie są w stanie wytworzyć większą wartość niż ta, jaką każdy z nich byłby w stanie osiągnąć jedynie we własnym zakresie.

\section{Odpowiedzialność}

Ta ważna kwestia, tworząca osnowę relacji usługowej, pojawia się jako odpowiedzialność niewymuszona (inforcible resposibility), co wskazuje na jej etyczne,

\footnotetext{
${ }^{12}$ Odwołuję się tu polemiki P. Ricoeura z R. Girardem, w której ten pierwszy dostrzega w darze nie tylko ofiarę, wyrzeczenie i poświęcenie, ale nade wszystko dobrowolną ofiarę (Ricoeur, 2013, s. 216-217).
} 
a nie wyłącznie prawne pochodzenie ${ }^{13}$. Nie umniejszając znaczenia, jakie nabywa odpowiedzialność wyprowadzana z uprawnień władczych i zakresu przyznanych obowiązków. Tym razem chodzi o odpowiedzialność za inne Ty przed samym sobą. Wskazuje się różne źródła tak rozumianej odpowiedzialności. Są nimi: elementarna ludzka com-patia, wynikająca ze wspólnoty losu; zobowiązania, jakie wiążą istoty duchowe (Weil, b.d.), ale też wyprowadzone zostają ze stosunku zawierzenia-zaufania, jak u E. Levinasa czy H. Jonasa. Dla przyjętego tu usługowego kontekstu, odpowiedzialność zasadza się na zaufaniu, jakim zlecający obdarował usługodawcę, powierzając mu swój problem, nierzadko bardzo osobistą sprawę. Powierzony pieczy usługodawcy problem/sprawa/rzecz rodzi zobowiązanie wobec usługobiorcy. Oczywiście byłoby brakiem odpowiedzialności ze strony wykonawcy zawieść oczekiwania i zaufanie zlecającego. Ale podążając za myślą H. Jonasa (1996, s. 172), na takim poziomie wyjaśniania nie poprzestaję, dostrzegam więc - dający się jasno określić - nieodwracalny stosunek odpowiedzialności. Jako wykonawca przejmuję oczywiście nadzór nad powierzoną mi sprawą, ale ten nadzór pociąga jednocześnie za sobą moje zobowiązania wobec zlecającego.

Ponieważ kwestia odpowiedzialności wprowadzona została w wymiar systematycznie prowadzonej działalności, dlatego też Kantowska dyrektywa moralna: możesz, albowiem powinieneś, zdaniem H. Jonasa, ulega modyfikacji w formułę: powinieneś, albowiem działasz, a czynisz to, ponieważ możesz czynić (Jonas, 1996, s. 230). W odniesieniu do Kanta, chodzi o możność do podporządkowania skłonności obowiązkowi; u Jonasa natomiast, w wersji nie tyle uwspółcześnionej, co zegzystencjalizowanej, możność odnosi się do uchylenia przyczynowych skutków w świecie, które uwolnione, stawiają naprzeciw siebie owo „powinieneś” naszej odpowiedzialności.

W cytowanej tu książce H. Jonasa znaleźć można analizę - z zakresu teorii moralności - nie tyle samego przejścia od moge do powinienem, co wyjaśnienie zasadności takiego przejścia. Tamże rozpatrywany jest również przykład archetypowej odpowiedzialności fundowanej na relacji rodzic-dziecko. Dopowiedzieć więc tylko wypada, że również relacja usługodawca-usługobiorca, jak wcześniej starałem się wykazać, również pod tę formułę archetypowej relacji podpada, przybrawszy kulturowo zróżnicowane mutacje w rodzaju: nauczyciel/mistrzuczeń, lekarz/pielęgniarka-pacjent, urzędnik-petent, czy doradca prawny i jego - powiedzmy - klient.

Jeśli jednak przyjąć zobowiązujący charakter podejmowanych wyborów i rozstrzygnięć, to musimy również zaakceptować, będące ich następstwem, przezwyciężanie wyjściowej a-symetryczności. Nadając świadczeniu rys spotkania,

\footnotetext{
${ }^{13}$ Kodeks cywilny, wyznaczając prawa i obowiązki stron związanych umową zlecenia, określa również zakres ich odpowiedzialności.
} 
odpowiedzialny usługodawca ma uzasadnione powody, by oczekiwać ze strony usługobiorcy adekwatnych zachowań. Lojalność - jeśli ją traktować serio - jest instancją dwustronnie wiążącą. A przekształcenie klienta w interesariusza można uznać za formalne potwierdzenie tego, że zasada odpowiedzialności za (w miejsce zasady odpowiedzialności przed) wiąże obie strony.

\section{Dobrostan}

Gdzieś między wyznaczaną przez statystyków „jakością życia"14 a aksjologicznym ,życiem godziwym”, sytuuje się „dobrostan”. Jego pojawienie się i spopularyzowanie jest skutkiem zmian, jakie dokonały się we współczesnej psychologii, doprowadzając do wyodrębnienia się „psychologii pozytywnej”. W opiniach czołowych adherentów, jest ona nie tylko kontynuatorką psychologii humanistycznej, ale nie kryje nawiązań do eudajmonizmu, korzeniami sięgającego czasów Sokratesa. Oczywiście tamta starożytna jedność (dobro i szczęście są tożsame) poddawana jest dzisiaj wnikliwej interpretacji, w której psychologowie mają znaczący udział. Można się, choćby częściowo, z nim zapoznać dzięki zredagowanej przez J. Czapińskiego książce (2004), której część druga stanowi źródło opracowania tego fragmentu.

Dzięki wspomnianemu wyżej usytuowaniu psychologii pozytywnej, jej ustalenia wpływają zarówno na interpretowanie znaczenia cywilizacyjno-materialnych podstaw życia szczęśliwego, jak i na zrozumienie głębszych motywów osiągania tego stanu. $Z$ wielości interesujących wątków tematycznych przewijających się w cytowanej publikacji, wydobywam jedynie te, które - moim zdaniem - znajdują bezpośrednie powiązanie $\mathrm{z}$ udziałem usług $\mathrm{w}$ tworzeniu owego dobrostanu.

\section{Transcendowanie zamiast zaspokajania}

Pomijam tu opis negatywnych zjawisk będących następstwem rozwoju cywilizacyjnego. W wypracowanych przez psychologię pozytywną koncepcjach znaleźć można starania przezwyciężenia behawioralnego modelu człowieka i wypracowania stanowiska bliskiego antropologii (filozoficznej łącznie z kulturową) $)^{15}$. Sednem tych poszukiwań jest weryfikacja podstawowych założeń modelu człowieka osadzonego na imperatywie zaspokajania stale rosnących potrzeb. Oprócz radykalnego rozróżnienia potrzeb od pragnień, co stało się przede wszystkim udziałem S. Weil (1965), M. Seligman proponuje oddzielenie przyjemności

\footnotetext{
${ }^{14}$ Zgodnie ze współczesnym rozumieniem jakości - ,,jakość życia” jest kategorią skwantyfikowaną, a jej poziom mierzony jest osiąganiem określonych stanów nasycenia.

${ }^{15}$ Godne wyróżnienia są tutaj koncepcje M. Seligmana (omawiane przez J. Czapińskiego w zredagowanej przez niego książce Psychologia pozytywna), a także teoria flow: ta ostatnia dostępna polskiemu czytelnikowi w osobnej publikacji M. Csikszentmihalyiego (Przepływ, Taszów 2005).
} 
(wynikającej z chwilowej prywacji, doraźnego smakowania nowości czy bezmyślnego chłonięcia wrażeń) od gratyfikacji. Ta ostatnia jest już czymś trwalszym, jest oddaniem się bez reszty temu, co się robi, zaangażowaniem w działanie ujawniające mocne strony i cnoty człowieka. Zauważmy rzadki, bo nawiązujący do McIntyera przykład wyjaśnienia motywów zachowań i dążeń ludzkich przez odniesienie do kategorii cnót. Gratyfikacje, których dostarcza postępowanie zgodne $\mathrm{z}$ osobistym profilem, oczywiście nie zakładają braku pozytywnych doznań emocjonalnych czy też przejawiania się samoświadomości. „Aby jednak nasze życie nabrało prawdziwego sensu, swoje mocne strony powinniśmy starać się wykorzystywać na rzecz czegoś, co wykracza poza nas samych (dla dobra innych ludzi, idei, kultury, cywilizacji)" (Weil, 1965, s. 78).

Ostatnie zdanie pozwoliłem sobie podkreślić, ponieważ tworzy ono łącznik między rozwijaną tu pozytywną teorią usług a psychologią pozytywną przywołaną wyżej w selektywnie skondensowanej formie. Łącząc oba podejścia można by następstwa synkretycznego myślenia wyrazić takimi słowy: Aby nasze życie nabrało sensu, musimy wyrwać się z materialnego kręgu zakreślonego imperatywem zaspokajania potrzeb, ponieważ być naprawdę człowiekiem znaczy być więcej niż tylko człowiekiem. Należałoby jeszcze dodać, iż takie pełniejsze, a więc i spełnione życie osiągnąć można otwierając się na przyciągające działanie wartości; dzięki pozytywnej odpowiedzi na oddziałujące na nas atraktory wartości.

\section{Dobrostan jako zmelioryzowana rzeczywistość}

Konkluzję, ku jakiej zmierzam, poprzedzić chciałbym wyrażeniem przekonania, że wszechstronna analiza pojęcia „usługa” naprowadza nas na kategorię dobrostanu. W skrótowej formie podane uzasadnienie wygląda następująco: Po pierwsze, chociaż wiele usług wyrasta $\mathrm{z}$ organicznego podłoża (i intensywność ich odczuwania znaczona jest pilnością potrzeb), to ze względu na interpersonalny charakter relacji usługowej, świadczenie jest wzbogacaniem, poprawą, udoskonaleniem istniejącego stanu rzeczy ${ }^{16}$. Po drugie, wraz z orientacją na lepiej i doskonalej pojawia się możliwość rozbicia bilateralnego układu, jaki powstać może między usługodawcą a usługobiorcą. Otwartość na inne Ty, daje o sobie znać zwłaszcza w usługach: osobistych, profesjonalnych oraz publicznych. Po trzecie, nierozerwalnie z usługami związany kontekst egzystencjalny sprawia, że organizacja usługowa wyjęta być powinna $\mathrm{z}$ abstrakcyjnego otoczenia rynkowego i wpisana w środowisko, w którym żyją jej klienci-usługobiorcy. To dlatego optuję wydzieleniem Lebensweltu. Pojęcie to, trudne do przetłumaczenia, oznacza środowisko nie tylko przysposobione, ale stale doskonalone po to, by mógł

${ }^{16} \mathrm{~W}$ obowiązującej tu definicji usługi określam następująco: usługa ... ma na celu wzbogacenie walorów osobistych bądź wolumenu użyteczności, Por. K. Rogoziński (2000). Usługi rynkowe. Poznań. 
zadomowić się w nim człowiek ${ }^{17}$. Po czwarte wreszcie, jednostkowego dobrostanu nie da się osiągnąć bez współudziału w tworzeniu dobra wspólnego. Jak wykazane zostało, chociaż usługa staje się Dobrem dla nabywcy, to jednak nie jest kategorią całkowicie „prywatną”. Nie staje się nią w takim zakresie, w jakim prywatna potrzeba staje się problemem uwzględniającym szerszy kontekst wraz ze społecznymi konsekwencjami. Zasadniczy trakt prowadzący od dobra jednostkowego do dobra wspólnego, wiedzie przez współpracę, zmierzając do osiągnięcia stanu zmelioryzowanej rzeczywistości, czyli dobrostanu.

\section{Bibliografia}

Archer, M. (2013), Człowieczeństwo. Problem sprawstwa. Kraków: Zakład Wydawniczy Nomos.

Bocheński, J.M. (1986). Ku filozoficznemu myśleniu. Warszawa: Instytut Wydawniczy PAX.

Csikszentmihalyi, M. (2005). Przepływ. Psychologia optymalnego doświadczenia. Taszów: Moderator.

Czapiński, J. (2004). Psychologiczne teorie szczęścia. W: J. Czapiński (red.). Psychologia pozytywna. Nauka o szczęściu, zdrowiu, sile $i$ cnotach człowieka. Warszawa: Wydawnictwo Naukowe PWN.

Elias, N. (2011). O procesie cywilizacji. Warszawa: WAB.

Elzenberg, H. (1991). Pisma z filozofii kultury. Kraków: Znak.

Jaspers, K. (1990). Filozofia egzystencji. Warszawa: PIW.

Jaspers, K. (1999). Wiara filozoficzna wobec objawienia. Kraków.

Jonas, H. (1996). Zasada odpowiedzialności, Etyka dla cywilizacji technologicznej. Kraków: Wydawnictwo Platan.

Kant, I. (1957). Krytyka czystego rozumu. T. 2. Warszawa.

Michalski, K. (1978). Heidegger i filozofia współczesna. Warszawa: PIW.

Ricoeur, P. (2013). Krytyka i przekonanie. Warszawa: KR.

Rogozinski, K. (2000). Ustugi rynkowe. Poznań: Wydawnictwo Akademii Ekonomicznej w Poznaniu.

Rogoziński, K (2000). Nowy marketing ustug. Poznań: Wydawnictwo Akademii Ekonomicznej w Poznaniu.

Stróżewski, W. (1992). W kręgu wartości. Kraków: Znak.

Tischner, J. (1974). Filozofia wypróbowanej nadziei. Znak, 237.

Weil, S. (1965). Świadomość nadprzyrodzona. Warszawa: Instytut Wydawniczy PAX.

17 „Ethos oznacza między innymi miejsce, na którym jakaś żywa istota „zadomowiła się”, które sobie wybrała jako naturalne dla niej miejsce pobytu, gdzie czuje się bezpiecznie i nie potrzebuje maskować siebie. Człowiek, jak wszystko, co żyje, szuka swojego „ethosu” — miejsca zadomowienia i kręgu swojskości. Otwiera się i mówi „od siebie”, gdy czuje, że stworzono mu lub sam sobie zdołał stworzyć coś z tej atmosfery. Zamyka się, gdy pogrąża się go w świecie obcym, wrogim, podejrzliwym” - pisał w eseju poświęconym Antoniemu Kępińskiemu, wybitnemu polskiemu psychiatrze, J. Tischner (1974). 
Weil, S. (b.d.). Pisma londyńskie i ostatnie teksty. Poznań.

Wojtyła, K. (1969). Osoba i czyn, Lublin.

\section{THE SELECTED CATEGORIES DEFINING INTERPRETATIVE CONTEXT OF SERVICES MARKETING}

Keywords: actualization, self-realization, perpetration, life, existence, gift, responsibility, welfare

Summary. This article presents six chosen categories of services marketing and discuss their significance for the essence of services marketing. The relational context of services marketing is the basis for the interpretation of the relationship service, assessing the role of the sides in this process and the nature of the obtained effect.

Translated by Izabela Ostrowska

\section{Cytowanie}

Rogoziński, K. (2016). Wybrane kategorie określające kontekst interpretacyjny marketingu usług. Marketing i Zarzadzanie, 1 (42), 267-282. 